\title{
Pengarusutamaan Berita Desa Oleh Gerakan Desa Membangun (GDM) Sebagai Upaya Kontrahegemonik
}

\author{
Tristia Riskawati ${ }^{1}$, Dede Mulkan \\ Yayasan Pembina Masjid (YPM) Salman ITB
}

\begin{abstract}
This research aims to understand the mainstreaming of village news by Gerakan Desa Membangun (Building Village Movement). The method used is collective case study using an approach of critical paradigm. Desa Melung, Kabupaten Banyumas and Desa Cibiru Wetan, Kabupaten Bandung are observed. The research shows that mainstreaming of village news by Building Village Movement is an endeavour of contra-hegemony because it attempts to create an alternative media as a rival to mainstream media. The mainstreaming of village news by Building Village Movement is significant in encouraging villagers to share informations as well as attracting academics attention to its movement.
\end{abstract}

Keywords: contrahegemony, hegemony, mainstreaming, village building

\begin{abstract}
Abstrak
Penelitian ini menelusuri pengarusutamaan berita desa oleh Gerakan Desa Membangun (GDM). Metode yang digunakan adalah penelitian kualitatif dan strategi penyelidikan studi kasus kolektif dengan paradigma kritis. Penelitian dilakukan terhadap dua desa peserta program GDM yaitu Desa Melung, Kabupaten Banyumas dan Desa Cibiru Wetan, Kabupaten Bandung. Hasil penelitian menunjukkan upaya pengarusutamaan berita desa yang dilakukan GDM merupakan upaya kontrahegemonik karena berupaya membuat tandingan berupa pengadaan media alternatif. Pengarusutamaan yang dilakukan oleh GDM signifikan dalam hal menjaring warga desa untuk saling berbagi informasi bahkan menarik perhatian akademisi untuk menelaah tentang gerakan mereka.
\end{abstract}

Kata kunci: arus utama, hegemoni, kontrahegemoni, membangun desa

\footnotetext{
${ }^{1}$ Korespondensi Penulis :

Tristia Riskawati, Yayasan Pembina Masjid (YPM) Salman ITB, Jalan Ganesha no. 7 Bandung

halotristi@gmail.com
} 


\section{Pendahuluan}

Teknologi informasi merupakan sarana belajar bagi siapapun yang dapat mengakses dan menggunakannya dengan bijak. Dalam perkembangannya, teknologi internet memungkinkan setiap orang untuk menyampaikan informasi atau mengakses informasi, atau membuat setiap orang, sekumpulan orang, atau masyarakat sebuah desa misalnya, membuat informasi tentang desanya sendiri. Informasi tentang desa sendiri juga menjadi alternatif informasi dari serbuan informasi yang biasanya datang dari media besar yang berpusat di Jakarta.

Yana Noviadi, Kepala Desa Mandalamekar, Kecamatan Jatiwaras, Kabupaten Tasikmalaya, berinisiatif membangun desa dengan potensi sendiri tanpa harus bergantung pada tatanan pemerintah di atasnya. Salah satu strategi yang dapat diadaptasi secara murah dan mudah bagi desa adalah memanfaatkan internet. Melalui pertimbangan tersebut, Desa Mandalamekar memiliki portal informasi tersendiri, http://mandalamekar.desa.id. Terbukti dalam beberapa bulan, hasil ketekunan bersuara di internet membuat desa ini dikenal hingga mancanegara (Paramita, 2013).

Teknologi informasi merupakan sarana pendukung lingkaran pembelajaran desa-desa lain yang ingin belajar dari Desa Mandalamekar. Teknologi ini menjadi media untuk mempertemukan desa-desa yang ingin bergerak bersama dalam semangat "Desa Membangun". Seperti dinyatakan juru bicara Gerakan Desa Membangun, Yossy Suparyo, melalui portal informasi Desa Mandalamekar, desa-desa di daerah Banyumas, Jawa Tengah pun belajar dari pengalaman Desa Mandalamekar dalam tata kelola mata air dan hutan rakyat.

Konsep ini kemudian berkembang menjadi sebuah gerakan sosial yang meluas. Gerakan ini menarik banyak pihak untuk ikut bergotong-royong sesuai dengan kemampuan dan keahlian masing-masing mendampingi desa. Oleh karena makin meluasnya gerakan sosial tersebut, lahirlah Gerakan Desa Membangun (GDM) pada tanggal 24 Desember 2012 di Desa Melung, Kelurahan Kedung-banteng, Kabupaten Banyumas. Menurut Yossy, pelopor dari GDM ini adalah para kepala desa dan perangkat desa yang menyadari bahwa desa perlu bertindak aktif dan menunjukkan kinerjanya pada publik.

Berdasarkan latar belakang yang telah dipaparkan, peneliti tertarik untuk mengetahui bagaimana proses literasi informasi dan media berlangsung dalam pengarusutamaan berita desa oleh gerakan desa membangun (GDM)? Penelitian dilakukan di dua desa yang tergabung di dalam Gerakan Desa Membangun (GDM), yaitu Desa Melung, Kecamatan Kedungbanteng, Kabupaten Banyumas, Jawa Tengah, dan Desa Cibiru Wetan, Kecamatan Cileunyi, Kabupaten Bandung, Provinsi Jawa Barat. Portal informasi Desa Melung melung.desa.id tergolong aktif menyampaikan berbagai kabar terbaru perihal desanya. Akun media sosial Twitter Desa Melung, @desamelung, juga aktif menyampaikan kabar setiap hari. Sebaliknya, portal informasi Desa Cibiru Wetan tergolong pasif (http://cibiruwetan. desamembangun.or.id/), sering kali lama tidak menyampaikan informasi. 
Pemilihan kedua desa tersebut bukan didasarkan sebagai contoh atau sampel kasus Gerakan Desa Membangun, namun lebih kepada perbedaan kondisi, dimana variasi kondisi ini dapat memberi informasi dan pengetahuan tentang dinamika pengalaman membangun literasi media melalui pengarusutamaan berita desa oleh Gerakan Desa Membangun. Kondisi perkembangan inovasi teknologi komunikasi dan informasi (TIK) di wilayah yang melingkupi kedua desa tersebut memberi pemahaman tentang dinamika hubungan antara ketersediaan TIK dengan keaktifan portal desa. Desa Melung yang menjadi bagian Kabupaten Banyumas, dengan portal desanya yang aktif justru berada di Kabupaten Banyumas, sebuah kabupaten yang tingkat perkembangan TIK-nya tidak terlalu maju dibandingkan daerah tingkat dua lainnya di Indonesia. Sedangkan portal desa Desa Cibiru Wetan yang berbatasan dengan Kota Bandung justru tidak aktif. Kota Bandung merupakan salah satu dari lima kota yang memiliki reputasi dalam perkembangan TIK di samping Jakarta, Yogyakarta, dan Makassar (Raharjo, 2014). Desa Melung lebih giat dalam mengelola situs mereka ketimbang Desa Cibiru Wetan yang dekat dengan kota berinovasi TIK tinggi.

Lebih lanjut, penelitian ini diarahkan untuk mengetahui bagaimana gambaran umum tentang hegemoni paradigma tentang perdesaan terhadap masyarakat; bagaimana aktivitas pengelolaan media komunitas masyarakat Desa Cibiru dan Desa Melung; serta bagaimana dinamika pengarusutamaan berita desa yang dilakukan oleh GDM pada masyarakat Desa Cibiru dan Desa Melung?

\section{Metode Penelitian}

Sesuai dengan permasalahan, tujuan dari penelitian, penelitian ini akan menggunakan metode penelitian kualitatif. Sebagaimana dinyatakan Creswell (1998) penelitian kualitatif didefinisikan sebagai sebuah proses penyelidikan untuk memahami masalah sosial atau masalah manusia yang didasarkan pada penciptaan gambaran holistik lengkap yang dibentuk dengan kata-kata, melaporkan pandangan informan secara terperinci, dan disusun dalam sebuah latar alamiah.

Pemilihan paradigma kualitatif diharapkan dapat menjawab pertanyaan tentang aktivitas pengelolaan media komunitas di kedua desa, mendeskripsikan apa yang sedang, akan, dan sudah dicapai GDM dalam dinamika pemberdayaan desa-desa yang tergabung dalam jejaring GDM, termasuk mengeksplorasi tantangan dan kendala yang dihadapi. Hal ini dilakukan dengan mengeksplorasi data yang didapat dari observasi, wawancara informan/partisipan, dan pemahaman dari bentuk opti-malisasi pemberdayaan desa yang dapat dijadikan parameter. Keunikan GDM sebagai jejaring media komunitas antar desa, membuat peneliti memilih pendekatan studi kasus agar mendapatkan deskripsi lebih mendalam mengenai gerakan tersebut. Studi kasus tunggal sering kali bisa digunakan untuk mencapai tujuan eksplanatoris, tak sematamata eksploratoris (atau deskriptif). Tujuan penganalisis dalam hal ini hendaknya untuk memajukan penjelasan-penjelasan tandingan untuk rangkaian peristiwa yang sama dan menunjukkan bagaimana penjelasan semacam itu mungkin bisa diterapkan pada situasi-situasi yang lain. 
Pertanyaan-pertanyaan "bagaimana" dan "mengapa" pada dasarnya lebih eksplanatoris dan lebih mengarah ke penggunaan strategi-strategi studi kasus, historis, dan eksperimen. Hal ini disebabkan pertanyaan-pertanyaan seperti ini berkenaan dengan kaitan-kaitan operasional yang menuntut pelacakan waktu tersendiri, dan bukan sekadar frekuensi atau kemunculan (Yin, 2005).

Secara spesifik, penelitian ini akan menggunakan desain penelitian studi kasus kolektif yang dirumuskan oleh Robert E. Stake. Menurut Stake (2009), berang-kat dari observasi dalam hal kesinambungan media komunitas masing-masing desa dalam memberitakan informasinya (satu desa konsisten, satu desa inkonsisten), peneliti tertarik meneliti faktor-faktor yang mendukung keberhasilan atau kegagalan keberjalanan media komunitas dua desa tersebut kendati menginduk pada konsep jejaring yang sama, yaitu Gerakan Desa Membangun.

Dalam studi kasus kolektif, seorang peneliti dapat meneliti sejumlah kasus secara bersamaan agar dapat meneliti fenomena, populasi, atau kondisi umum. Stake mengatakan kumpulan-kumpulan kasus yang diteliti bisa saja sama atau berbeda. Keberulangan dan keragaman masing-masing memiliki pesan. Keduanya dipilih karena diyakini bahwa dengan memahaminya, peneliti akan diantarkan pada pemahaman yang lebih baik atau bahkan perumusan teori yang lebih baik.

\section{Kajian Pustaka}

\section{Hegemoni dan Kontrahegemoni}

Sebagaimana halnya Marx, Gramsci memandang ideologi sebagai pelayan kepentingan kelas yang berkuasa. Oleh karena itu, menurut Gramsci, sebagian dari perjuangan rakyat harus diarahkan pada level ideologis dengan cara menentang ideologi budaya yang dominan dan beralih pada ideologi pembebasan sosial. Menurut Gramsci, ideologi bukan hanya alat untuk menutupi kepentingan kelas yang berkuasa, tetapi dapat juga menjadi artikulasi kepentingan yang nyata dari kelas-kelas subordinat. Upaya bentuk perlawanan masyarakat atas keunggulan atau supremasi melalui kepemimpinan intelektual dan moral atas dukungan kekuatan dan persetujuan dinyatakan sebagai kontrahegemoni.

Proses kontrahegemoni sendiri menurut Gramsci berlangsung secara gradual, mulai dari mempertanyakan nilai-nilai dan asumsi-asumsi budaya yang dominan, dalam bentuk skeptisisme dan keraguan akan nilai-nilai dalam sistem kepercayaan atau pandangan dunia yang dominan, diikuti oleh langkah-langkah lain yang pada gilirannya akan menunjukkan kontradiksi-kontradiksi yang tersembunyi dalam diskursus hegemoni. Hal ini kemudian akan mengarah pada penciptaan gagasan dan nilai-nilai yang sama sekali baru.

Dalam konteks teori hegemoni Gramsci, media massa adalah alat yang dipergunakan oleh kelompok elite untuk mengabadikan kekuasaan, kesejahteraan dan status melalui penciptaan popularisasi filosofi, budaya, dan moral mereka. Namun media juga mampu menciptakan, memperkuat, mendukung atau bahkan meruntuhkan 
sebuah hegemoni berdasarkan kecenderungan institusi media yang juga memiliki ideologi sendiri. Dengan demikian, media juga dapat dipergunakan untuk menyebarluaskan dan memperkuat ide-ide civil society.

\section{Hasil dan Pembahasan}

\section{Hegemoni Paradigma tentang Perdesaan terhadap Masyarakat}

Pembangunan berorientasi pertumbuhan (growth) selama ini banyak diterapkan negara-negara berkembang. Di Indonesia, konsep ini telah membawa sejumlah prestasi. Namun di sisi lain manfaat pembangunan lebih dirasakan oleh kelompok masyarakat lapisan atas, sehingga terjadi kesenjangan sosial dan ekonomi. (Tarigan, 2009). Karena pembangunan tidak hanya terkait dengan peningkatan ekonomi, namun juga berbagai aspek lain terutama menyangkut pembangunan manusia. Seperti dinyatakan peraih nobel ekonomi, Amartya Sen, pembangunan adalah realisasi dari kebebasan dan penghapusan ketidakbebasan seperti kemiskinan, kelaparan, dan hambatan bagi pemenuhan hak-hak politik. Sen juga mengingatkan pentingnya memperluas definisi pembangunan mencakup kebebasan manusia untuk bidang politik, fasilitas ekonomi, kesempatan sosial, jaminan transparansi, dan perlindungan, serta keamanan (Terjesen, 2004).

Orientasi pembangunan ekonomi Indonesia yang lebih menekankan pertumbuhan ini juga memperparah ketimpangan wilayah, khususnya antara desakota. Undang-undang RI Nomor 25 Tahun 2000 Tentang Propenas, Bab IX Pembangunan Daerah dengan tegas menyebutkan: sebagian besar masyarakat perdesaan saat ini masih berada pada pola kehidupan dan budaya perdesaan yang mengandalkan sumber kehidupan dari pertanian subsisten atau buruh tani yang pendapatannya tidak pasti dan rendah.

Pertentangan dan ketimpangan antara kawasan perkotaan (urban area) dan kawasan kawasan perdesaan (rural area) tidak saja terjadi dalam tataran praktek operasional namun juga telah merambah ke dalam tataran teoritik - akademik. Di satu sisi, fenomena terjadinya "pemihakan" yang berlebihan terhadap upaya-upaya pembangunan kawasan perkotaan secara akademik telah diklaim oleh Lipton (1977) sebagai urban bias, yang notabene telah banyak merugikan penanganan kawasan perdesaan (Tarigan, 2009). Kesenjangan inilah yang membuat desa seringkali identik dengan kemiskinan, keterbelakangan, kebodohan, minim infrastruktur, hingga pelayanan publik yang buruk. Kecenderungan stigma yang melekat pada masyarakat pedesaan selalu diidentikkan dengan perilaku dan sikap yang dianggap kolot dan tradisional, yang dilawankan dengan sikap dan perilaku orang kota yang maju dan modern.

Memasuki era reformasi, Indonesia memiliki Undang-Undang Nomor 22 Tahun 1999 tentang Pemerintahan Daerah. Pakar pemerintahan dari Universitas Padjadjaran, Dede Maryana, menilai terdapat lompatan luar biasa bila dibandingkan dengan rumusan tentang desa dalam undang-undang sebelumnya. Secara normatif, UU 
No.22/1999 menempatkan desa tidak lagi sebagai bentuk pemerintahan terendah di bawah camat, melainkan sebagai kesatuan masyarakat hukum yang berhak menga-tur dan mengurus kepentingan masyarakat setempat sesuai dengan hak asal-usul desa. Implikasinya, desa berhak membuat regulasi desa sendiri untuk mengelola barangbarang publik dan kehidupan desa, sejauh belum diatur oleh kabupaten. Desa menjadi bagian rumah tangga kabupaten/kota, setelah sebelumnya menjadi rumah tangga dari provinsi. Dalam perkembangannya kemudian muncul Undang-Undang Desa Nomor 6 Tahun 2016, yang mengatur antara lain tentang tujuan desa agar dapat berkembang secara mandiri, termasuk dalam aspek pembiayaan dimana desa akan mendapat alokasi dana desa dari Anggaran Perencanaan dan Belanja Negara (APBN).

Kendati desa sudah disuguhi UU yang memfasilitasi mereka untuk mandiri, namun banyak di antara mereka yang belum siap. Asisten Peneliti di Manajemen dan Kebijakan Publik, Arif Novianto, agenda otonomi daerah yang sudah berjalan sekitar satu dasawarsa tak lebih sebagai transfer tindakan koruptif dan penyelewengan dari pusat ke daerah. Walhasil, sekarang ini muncul fenomena "raja-raja" di berbagai daerah. Rakyat hanya bisa mengigit jari. Kehidupan mereka jarang tersentuh oleh tangan gaib mekanisme pasar yang diusung oleh pemerintah pusat dan daerah melalui ideologi neoliberalisme (Harian Haluan, 2014).

Hal yang menjadi permasalahan utama adalah ketika basis struktur (neoliberal) yang ada sangat bertolak belakang dengan tujuan dari otonomi desa ini. Pemerintah desa pun tak bisa apa-apa, karena hegemoni dari neoliberalisme ini telah merasuki kewenangan-kewenangan dari pemerintah pusat yang tidak mungkin ditentang pemerintah desa (secara formal).

Yossy Suparyo, Juru Bicara Gerakan Desa Membangun (GDM) berpendapat bahwa praktik pembangunan perdesaan cenderung dari atas ke bawah (top-down) dibanding dari bawah ke atas (bottom-up). Akibatnya, desa sekadar menjadi objek pembangunan, bukan sebagai subjek pembangunan. Desa tidak diberi kewenangan lebih dalam mengelola sumber daya yang ada di wilayahnya. Yossy menyebut ini sebagai jargon "Membangun Desa". Berikut pemaparan Yossy terhadap penjelasan jargon ini:

Selama ini desa hanya memiliki peran perencanaan pembangunan abal-abal, karena program pembangunan yang dilaksanakan atau dibiayai masih ditentukan oleh pihak supradesa (kabupaten, propinsi, pusat). Jadi yang terjadi sebenarnya pembangunan di desa, bukan pembangunan desa. GDM merupakan refleksi atas itu, sehingga "Desa Membangun" bukan "Membangun Desa" (Suparyo, Wawancara Peneliti, 2014).

Pradna Paramita, anggota dari Komunitas Blogger Banyumas dalam makalahnya yang berjudul "Strategi Pengarusutamaan Berita Desa" mengatakan, jargon "Membangun Desa" justru pada prakteknya seringkali membebani desa. Hal ini diakibatkan oleh pemaksaan program atau kebijakan yang tidak sesuai dengan kondisi kebutuhan desa. 
Hegemoni yang terjadi di desa, baik dari pusat pemerintahan langsung (Jakarta), ataupun melalui elit-elit pemerintahan lokal juga termasuk hegemoni dalam tataran informasi. Masyarakat yang tinggal di luar Jakarta termasuk masyarakat desa terbiasa ditempa oleh informasi-informasi yang tidak relevan dengan apa yang terjadi di lingkungan mereka. Pemerintah lokal meneguhkan hegemoni tersebut dengan membiarkan terpaan informasi-informasi tersebut diserap oleh masyarakat. Pengarusutamaan berita-berita yang terpusat dari sudut pandang Jakarta, lewat konglomerasi media, menjadi ajang hegemoni tatanan industri media Indonesia saat ini.

Menurut Pradna, dalam makalahnya "Strategi Pendampingan Pengarusutamaan Berita Desa", suara desa selama ini telah terpinggirkan karena media-media arus utama (media mainstream) lebih memilih menyajikan berita yang "layak jual", sensasional dan "Jakarta sentris". Dalam konteks desa, Pradna berpendapat tatanan media yang dikuasai oleh korporasi-korporasi besar yang bersarang di Jakarta ini dapat "meminggirkan" suara masyarakat desa.

Akademisi Universitas Padjadjaran, Kunto Adi Wibowo, dalam penelitiannya yang berjudul "Melipat Indonesia dalam Berita Televisi" menyebutkan sepuluh siaran media televisi besar masih berisi konten yang didominasi berita seputar Jakarta (Gatranews, 2014). Namun, tidak hanya media yang bisa mempengaruhi masyarakat.

Konten-konten informasi ini tentu sedikit banyak akan mempengaruhi kehidupan mereka. Media massa juga bisa dianggap menciptakan lingkungan semu tersendiri di antara manusia dan dunia "nyata" objektif. Media menebalkan dunia semu sehingga menambah jarak antara manusia modern dengan dunia nyata. Sebagai institusi kontrol sosial yang dominan, media bisa memperkuat nilai-nilai dan pandangan lama di suatu masyarakat dan bisa membuatnya stagnan (Rivers, etc, 2008, pp. 36-37). Pandangan lama yang diperkuat oleh media arus utama adalah nilai-nilai dan budaya Jakarta yang cenderung sensasional ketimbang mendidik. Masyarakat yang mengakses media seperti suratkabar, radio, televisi, dan internet pun mau atau tidak mau terpapar oleh nilai-nilai yang dipromosikan oleh media tersebut.

Nilai-nilai dan budaya Jakarta yang tidak selamanya sesuai dengan keadaan masyarakat di seluruh penjuru Indonesia pun merasuki tatanan masyarakat baik di kota maupun desa. Penduduk kota bukan Jakarta dan desa pun sedikit banyak terpengaruh dengan paradigma Jakarta. Pengaruh itu dapat termanifestasi dalam keengganan untuk memajukan desa dan gaya hidup metropolitan masyarakat non-Jakarta yang tidak sesuai dengan kearifan lokal daerah-daerah non-Jakarta.

Konten-konten media arus utama pun dapat mentransformasi masyarakat, melalui nilai-nilai tertentu yang terdapat pada konten media tersebut. Disadari maupun tidak, media pun menggiring masyarakat Indonesia untuk bertindak sesuai dengan apa kata media arus utama. Contohnya adalah seperti yang disebutkan sebelumnya, yaitu bagaimana masyarakat desa pindah ke kota karena keadaan kota di media arus utama tampak lebih prospektif. 
Dalam sebuah makalah yang dirilis tahun 2014 oleh Badan Perencanaan Pembangunan Nasional, tingkat urbanisasi diproyeksikan sudah mencapai 68 persen pada tahun 2025. Tingkat urbanisasi di empat provinsi di Jawa pada tahun 2025 sudah di atas 80 persen, yaitu di DKI Jakarta, Jawa Barat, DI Yogyakarta, dan Banten (Data Statistik Indonesia, 2014). Kota-kota besar khususnya Jakarta masih menjadi daya tarik tersendiri bagi masyarakat untuk melakukan urbanisasi. Penduduk dari kota-kota kecil di Jawa dan luar Pulau Jawa menganggap Jakarta sebagai lokasi yang tepat untuk mencari lapangan pekerjaan (Pikiran Rakyat, 2013). Bisa jadi, selain faktor-faktor pertumbuhan ekonomi di perkotaan, berita-berita yang menggembar-gemborkan kehidupan kota dapat juga menjadi pemicu masyarakat untuk memenuhi kota.

Untuk itu, strategi rekognisi atas desa mutlak diperlukan. Strategi rekognisi menempatkan desa sebagai subjek pembangunan sehingga mereka menjadi ujung tombak dari perencanaan dan pelaksanaan pembangunan di wilayahnya. Strategi rekognisi melahirkan konsep desa membangun, bukan membangun desa. Hal ini membuktikan bahwa masyarakat Indonesia lebih banyak terpapar oleh berita-berita yang tak relevan bagi banyak publik di luar Jakarta.

Berangkat dari hal tersebut, Pradna bersama Yossy Suparyo (pegiat Gedhe Foundation), Yana Noviandi (Kepala Desa Mandalamekar, Tasikmalaya) merintis jejaring portal informasi bernama Gerakan Desa Membangun (GDM). Jejaring GDM dengan situsnya desamembangun.orid yang dibuat untuk menahan gempuran pengarusutamaan berita-berita "layak jual", sensasional, dan Jakarta sentris.

\section{Aktivitas Pengelolaan Media Komunitas Masyarakat Desa Cibiru dan Desa Melung}

Lahirnya Gerakan Desa Membangun tak lepas dari peran Kepala Desa Melung periode 2002-2013, Agung Budi Satrio (Budi). Budi yang berasal dari Jakarta pindah ke Desa Melung sekitar tahun 1998. Selama di Melung, Budi menjalin komunikasi dengan masyarakat setempat. Sejak tahun 2008, Budi yang pada saat itu sudah menjadi Kepala Desa Melung memutuskan untuk memasang internet menggunakan Telkom Flexi dari Grup Telkom. Pusat jaringan internet terdapat di rumah Budi. Lalu, oleh infrastruktur tertentu, akhirnya jaringan tersebut ditembakkan ke balai desa dan sekolah. Bagi Budi, berlangganan internet lebih menguntungkan ketimbang harus langganan koran per bulan.

Setelah jaringan internet dipasang, Budi menyadari bahwa selama ini ia dan warga Desa Melung baru sekadar mencari pengetahuan. Berita-berita tentang desa pun Budi nilai lebih banyak dipotret oleh orang luar. Oleh karena itu, Budi memiliki inisiatif untuk dapat memanfaatkan teknologi komputer dan internet. Budi berpendapat membayar wartawan untuk memberitakan desanya cukup mahal. Akhirnya, melalui perangkat teknologi informasi, mereka memanfaatkan bagaimana seluruh hal tentang desa baik potensi dan kegiatan-kegiatan tentang desa ternyata menarik. Program ini kemudian dilanjutkan oleh Kepala Desa berikutnya, Khoerudin. 
Menurut Khoerudin, berita-berita tentang desa selama ini lebih banyak yang jelek ketimbang yang bagus. Menurutnya, kemandirian terhadap data juga terkait kepada bagaimana desa dapat memanfaatkan situs desa mereka. Khoerudin yakin, internet dapat membantu desa untuk suatu menguasai berita.

"Maka dari itu, upaya untuk mengisi di internet itu tentang berita misalnya harapannya begini ... di Indonesia kan ada lebih kurang 73.000 desa. Nah, kalau masing-masing desanya memberitahukan tentang potensi atau kegiatannya, minimal 73.000 lah per harinya pada membuat. Nah, itu kan nanti di internet desa menguasai berita. Jadi beritanya mungkin, ya, sederhana, tapi mungkin lebih positif, karena mungkin, berbicara soal potensi, dan berbicara soal kegiatan di masing-masing desa." (Khoerudin, 2014).

Sementara itu, Budi sendiri banyak bergaul dengan beragam orang-orang dari lembaga swadaya masyarakat (LSM) di Banyumas seperti Komunitas Blogger Banyumas dan BlankOn Banyumas. Koneksinya dengan orang-orang LSM mempertemukannya dengan Jalu Sungging Septianto, warga Desa Karang Nangka yang mengenalkan Budi dengan Yossy Suparyo, anggota Komunitas Blogger Banyumas dan Direktur Gedhe Foundation pada pertengahan 2010. Dari Yossy, Budi belajar bagaimana belajar komputer dan berinteraksi lewat jaringan internet.

Sebenarnya, sudah ada desa yang menggunakan internet untuk mengabarkan secara mandiri mengenai berbagai hal yang terjadi di desa mereka, yaitu Desa Mandalamekar Kecamatan Jatiwaras, Kabupaten Tasikmalaya melalui mandalamekar.wordpress.com untuk portal berita desa mereka. Melihat inovasi Desa Mandalamekar dalam memanfaatkan teknologi, salah satu LSM dari Yogyakarta bernama Institute for Education Development, Social, Religious, and Cultural Studies (INFEST), berkunjung ke Desa Mandalamekar untuk membuatkan mereka situs portal berita.

Teknologi informasi merupakan sarana pendukung lingkaran pembelajaran desa-desa lain yang ingin belajar dari Desa Mandalamekar. Teknologi ini menjadi media untuk mempertemukan desa-desa yang ingin bergerak bersama dalam semangat “Desa Membangun”. Melalui portal informasi Desa Mandalamekar, desa-desa lain di daerah Banyumas, Jawa Tengah pun belajar dari pengalaman Desa Mandalamekar dalam tata kelola mata air dan hutan rakyat. Margino, Pemimpin Redaksi melung.desa.id mengatakan:

"GDM itu lahirnya di sini (Melung). Itu kan ada salah satu desa di Jawa Barat, Mandalamekar. Itu desa yang sebenarnya, kawan-kawan di INFEST Yogya, berkunjung ke sana lalu membuatkan situs desa, mandalamekar.or.id. Kemudian, ada kawan di Purwokerto yang menghubungkannya dengan kita. Terus kemudian setelah dikenalkan, kita juga dibuatkan situs." (Margiono, 2014).

GDM lahir dari pengalaman desa-desa untuk mendorong inisiatif pembangunan bottom up, tata kelola sumber daya yang berkelanjutan, dan penyelenggaraan layanan publik yang baik. Pelopornya adalah para kepala desa dan 
perangkat desa yang menyadari bahwa desa perlu bertindak aktif dan menunjukkan kinerjanya pada publik, termasuk Yana Noviadi dari Desa Mandalamekar dan Agung Budi Satrio dari Desa Melung.

Budi berpendapat, GDM merupakan sindiran halus terhadap pemerintah bahwa desa seolah-olah selalu diberi. Baginya desa juga mampu memberikan sesuatu kepada semua orang. Biasanya orang lain yang membangun desa, kini dibalik bagaimana desa mampu membangun dirinya sendiri.

"Sebenarnya GDM ini mengkritisi dengan melakukan dulu. Mengkritisi tidak hanya mahasiswa turun ke jalan. Tapi kita melakukan hal-hal yang baik dulu. Misal desa sudah memperjuangkan subdomain sendiri, tinggal kabupaten memanfatkan itu. Kalau saya bupati, tinggal saya memantau situs-situs desa..." (Satrio, 2014).

Dalam pelaksanaannya, GDM memiliki tugas utama sebagai berikut:

1. Mendorong penyelenggaraan pelayanan publik yang baik, efektif dan efisien.

2. Pengembangan tata perencanaan, penganggaran, pelaksanaan pembangunan yang akuntabel dan transparan.

3. Mengelola sumber daya desa yang berkelanjutan dengan kearifan kolektif masyarakat desa.

4. Penerapan teknologi tepat guna secara mandiri dan berbasis sumber terbuka (open source).

5. Perlindungan warga desa yang migrasi ke luar negeri atau buruh migran.

6. Dinamika pengarusutamaan berita desa yang dilakukan oleh GDM pada masyarakat desa cibiru dan desa melung adalah upaya kontrahegemonik.

Upaya GDM, dalam konteks melawan hegemoni berita yang berpusat pada Jakarta atau Jakarta sentris, dapat disebut sebagai upaya menciptakan kontrahegemoni. Proses kontrahegemoni yang berlangsung secara gradual diwujudkan melalui proses perjuangan pembuatan media sendiri atau media komunitas yang mewujud melalui program dari bawah (dari rakyat) yang diberi nama Gerakan Desa Membangun. Warga desa yang dimotori oleh beberapa tokoh, termasuk Budi menyadari pentingnya membangun media sendiri untuk melawan media arus utama.

'Kita ketahui bahwa media arus utama, seperti TV, koran, itu lebih sedikit berita tentang desa, nah, dari situlah kami dari GDM ingin mencoba bagaimana desa punya ruang di media untuk bersuara. Kalau kita harus membayar wartawan cukup mahal, akhirnya kita melalui perangkat teknologi informasi kita manfaatkan bagaimana seluruh hal tentang desa baik potensi dan kegiatankegiatan tentang desa ternyata menarik juga.' (Wawancara peneliti dengan Agung Budi Satrio pada 4 Juni 2014 di kediamannya di Desa Melung, Kecamatan Kedungbanteng, Kabupaten Banyumas)

Budi terhitung sebagai pribadi yang senang bersosialisasi dengan kalangan pegiat Teknologi Informasi dan Komunikasi (TIK) di Purwokerto. Berkat dengan jejaring pertemanannya, akhirnya ia pun berkenalan dengan pegiat-pegiat lembaga swadaya masyarakat (LSM) berbasis TIK yang memiliki pandangan serupa 
dengannya. Budi kemudian berkenalan dengan Yossy Suparyo, anggota Komunitas Blogger Banyumas dan Direktur Gedhe Foundation pada pertengahan 2010. Dari Yossy, Budi belajar bagaimana belajar komputer dan berinteraksi lewat jaringan internet.

Yossy, yang juga merupakan pegiat dari LSM Institute for Education Development, Social, Religious, and Cultural Studies (INFEST) di Yogyakarta juga memiliki pandangan serupa tentang hegemoni terhadap desa. berpendapat bahwa praktik pembangunan perdesaan cenderung dari atas ke bawah (top-down) dibanding dari bawah ke atas (bottom-up). Akibatnya, desa sekadar menjadi objek pembangunan, bukan sebagai subjek pembangunan. Desa tidak diberi kewenangan lebih dalam mengelola sumber daya yang ada di wilayahnya. Yossy menyebut ini sebagai jargon "Membangun Desa". Asumsi "Membangun Desa" inilah yang Yossy pertanyakan.

Jargon "Membangun Desa" juga termasuk kepada bagaimana berita-berita dari pusat menyalurkan informasi-informasi yang berorientasi dengan nilai-nilai perkotaan dan tidak ada hubungannya dengan kepentingan perdesaaan. Pradna Paramita, yang juga tergabung ke dalam Gerakan Desa Membangun berpendapat, masyarakat yang tinggal di luar Jakarta termasuk masyarakat desa terbiasa ditempa oleh informasiinformasi yang tidak relevan dengan apa yang terjadi di lingkungan mereka. Pemerintah lokal meneguhkan hegemoni tersebut dengan membiarkan terpaan informasi-informasi tersebut diserap oleh masyarakat, bahkan dalam berbagai mendukung terpaan berbagai informasi yang belum tentu relevan tersebut.

Kontradiksi-kontradiksi yang tersembunyi dalam diskursus hegemoni yang dikemukakan para pegiat GDM dapat terlihat dari bagaimana mereka mempermasalahkan istilah "Membangun desa". Walaupun terdengar mulia, namun bagi Yossy istilah ini membuat desa sekadar menjadi objek pembangunan, bukan sebagai subjek pembangunan.

Baginya selama ini desa hanya memiliki peran perencanaan pembangunan abal-abal, karena program pembangunan yang dilaksanakan atau dibiayai masih ditentukan oleh pihak supradesa (kabupaten, propinsi, pusat). Hal yang sebenarnya terjadi sebenarnya "pembangunan di desa", "bukan pembangunan desa".

Berdasarkan kritik terhadap praktik pembangunan perdesaan oleh pemerintah supradesa yang cenderung dari atas ke bawah (top-down) yang diwakili dengan jargon "membangun desa", akhirnya, Yossy, Pradna, Budi, dan rekan-rekan mereka yang peduli terhadap kepentingan desa yang berdaulat pun menciptakan Gerakan Desa Membangun (GDM) yang pada akhirnya menciptakan jargon tandingan, yaitu "Desa Membangun". Dalam konteks pengarusutamaan berita desa, Pradna kemudian menyusun dan memublikasikan makalah yang memaparkan tentang langkah-langkah yang telah dilakukan oleh pendamping Gerakan Desa Membangun (GDM) dalam membantu mengarusutamakan berita desa, berjudul "Strategi Pendampingan Pengarusutamaan Berita Desa". Pradna membahas pula bagaimana pemanfaatan TIK, jejaring sosial, kerjasama, kegiatan dengan tujuan desa mampu bersuara sehingga 
potensi dapat dikenal. Diharapkan, strategi yang telah dipaparkan dapat menjadikan desa berdaya (karena potensi desa dikenal luas) dan bermartabat (mandiri dan tidak bergantung kepada bantuan).

Segelintir masyarakat yang memiliki kepedulian terhadap kepentingan desa dan sudah merumuskan beberapa nilai yang mereka anut pun kemudian bergabung dalam Gerakan Desa Membangun. Perangkat Desa Melung yang saat itu dikepalai Agung Budi Satrio mengumpulkan beberapa desa yang ada di Kabupaten Banyumas dan mengundang Kepala Desa Mandalamekar yang sudah membuat situs tentang desanya, Yana Noviadi, dalam sebuah lokakarya 24-26 Desember 2011 bersama INFEST.

Lokakarya yang mengajarkan seputar pemanfaatan teknologi dan informasi diikuti oleh Desa Melung, Desa Karangnangka, Desa Kutaliman, Dawuhan Wetan (Kedungbanteng, Banyumas) dan Desa Mandalamekar (Jatiwaras, Tasikmalaya). Pada momen itulah tercetus Gerakan Desa Membangun (GDM). Gerakan Desa Membangun bukan sekadar gerakan spontan yang kemudian menguap karena sampai saat ini GDM masih aktif dalam menyokong pembangunan desa yang lebih baik lewat pemanfaatan TIK. Bahkan, GDM pun turut terlibat dalam pembuatan Randangan Undang-Undang seperti RUU Desa dan RUU Pertanahan. Anggota dari desa membangun kini sudah mencapai 263 desa. Hal ini menunjukkan bahwa mereka berpotensi memiliki posisi yang kuat dalam perang posisi melawan hegemoni supradesa.

GDM lahir dari pengalaman desa-desa untuk mendorong inisiatif pembangunan bottom up, tata kelola sumber daya yang berkelanjutan, dan penyelenggaraan layanan publik yang baik. Pelopornya adalah para kepala desa dan perangkat desa yang menyadari bahwa desa perlu bertindak aktif dan menunjukkan kinerjanya pada publik.

Oleh karena GDM menyasar kepala desa dan perangkat pemerintahannya, maka struktur alternatif yang dipersiapkan oleh GDM berawal dari pemerintahan desa (Pemdes). Pemdes didorong untuk dapat mandiri mengabarkan potensi, aktivitas, dan hal-hal yang berkaitan dengan desa mereka sehingga pihak luar dapat melihat bahkan membantu mereka.

Yossy mengatakan, GDM menganut keberpihakan emansipatoris yang terilhami dari pemikiran Jurgen Habermas, sosiolog asal Jerman. Keberpihakan emansipatoris ala GDM diwujudkan melalui tiga cara, yaitu mendorong semakin banyak masyarakat perdesaaan untuk bersuara, kemampuan mengelola pengalaman organisasi menjadi pengetahuan ilmiah, dan mempengaruhi para penentu kebijakan publik untuk mengadopsi pengetahuan dan praktik baik tata kelola perdesaan dalam peraturan dan perundang-undangan (Suparyo, http://desamembangun.or.id/2013/09/strategi-menggalang-kekuatan-untuk-

lantangkan-isu-perdesaan/, 2013).

Dari tiga keberpihakan emansipatoris tersebut, GDM bukanlah sebuah gerakan subversif yang ingin mengubah tatanan struktur pemerintahan dengan tidak menaati perundangan-undangan. Justru, GDM berupaya melakukan advokasi dengan 
pemerintah atau DPR untuk dapat memfasilitasi desa kebijakan-kebijakan atau hukum yang dapat menunjang kedaulatan desa. Dengan ini, GDM tidak bertujuan untuk "mengganti struktur yang lama" namun "memperbaiki struktur yang lama".

\section{Pelajaran dari Desa Melung dan Desa Cibiru}

Dari hasil wawancara dan observasi, peneliti menemukan Desa Melung lebih giat untuk memanfaatkan TIK demi kepentingan desa mereka ketimbang Desa Cibiru Wetan. Desa Melung sendiri mengandalkan Margino, Kaur Keuangan Desa Melung untuk mengelola situs. Sedangkan Desa Cibiru Wetan mengandalkan Asep, Kepala Desa Cibiru Wetan itu sendiri. Perangkat desa pun acapkali turun ke masyarakat secara informal (misal: pada saat ronda) untuk mengajarkan internet. Sedangkan perangkat Desa Cibiru Wetan, yang memang sudah menguasai TIK belum memiliki kesadaran untuk mengajarkan hal tersebut kepada warga. Alasan yang dikemukakan Asep adalah, "perangkat desa punya urusan lain yang lebih membuat sibuk."

Indikator yang dapat menunjukkan mengapa Desa Melung lebih giat memanfaatkan TIK adalah keberlangsungan mereka dalam memproduksi kontenkonten di situs mereka. Terhitung sudah 399 konten yang mereka produksi dari tahun 2008. Sedangkan situs Desa Cibiru Wetan baru memproduksi 20 konten dari tahun 2013. Hal ini dapat dipahami karena situs Cibiru Wetan masih tergolong muda, ketimbang situs Melung yang sudah beroperasi sejak lama. Namun jika dihitung dari bulan pertama situs Desa Cibiru Wetan beroperasi, hanya terhitung 6 bulan yang terisi konten-konten mereka. Sedangkan Melung rutin menerbitkan ragam konten tiap bulannya.

Mengapa Desa Melung lebih produktif dan semangat berbicara dalam pemanfaatan TIK ketimbang di Desa Cibiru Wetan? Berdasarkan hasil observasi peneliti serta hasil wawancara peneliti dengan pakar psikologi sosial lulusan Universitas Indonesia, Adriano Rusfi, dan pakar TIK dari Institut Teknologi Bandung, Budi Rahardjo, terdapat beberapa faktor yang dapat menjelaskan mengapa pemanfaatan TIK di Desa Melung lebih hidup ketimbang pemanfaatan TIK di Desa Cibiru Wetan.

Pertama, Desa Melung adalah tempat di mana Gerakan Desa Membangun (GDM) pertama kali dideklarasikan pada 24-26 November 2011 dalam sebuah lokakarya pemanfaatan TIK. Berarti, GDM sudah menjangkau Desa Melung selama dua tahun lebih. Salah satu pendiri dan anggota GDM pusat pun, Agung Budi Satrio, kini masih menetap di Desa Melung dan bekerja pada Program Nasional Pemberdayaan Masyarakat Mandiri (PNPM Mandiri) desa tersebut. Adanya salah satu warga Desa Melung yang aktif dalam GDM pusat pun memperlancar arahan GDM untuk dilakukan oleh desa mereka. Desa mereka pun satu kabupaten dengan kantor pusat GDM yang berada di Desa Pangebatan, Kecamatan Karangleuwas, Kabupaten Banyumas atau berjarak 19,5 kilometer.

Sedangkan Desa Cibiru Wetan baru resmi mendatangkan GDM ke desa mereka pada pelatihan tanggal 23 November 2013 di Balai Desa Cibiru Wetan. Situs resmi 
mereka, cibiruwetan.desa.id, pun baru dirilis pada bulan yang sama dengan pelatihan tersebut. Jadi, program GDM di Cibiru Wetan baru berjalan selama tujuh bulan.

Selain itu, jarak antara Desa Cibiru Wetan dengan kantor GDM pusat pun beda provinsi (berjarak 255 kilometer). Hal ini membuat arahan-arahan GDM tidak terlalu lancar tersalurkan pada Desa Cibiru Wetan. Terlebih, perangkat desa, seperti yang dikatakan Asep Hasan Sadeli, memiliki kesibukan lain yang tidak berhubungan dengan pemanfaatan TIK.

Kedua, walaupun Kabupaten Banyumas (tempat di mana Desa Melung Berada) bukan termasuk daerah populer dalam perkembangan TIK, namun pegiatpegiat dari komunitas TIK di daerah tersebut memiliki minat tinggi dalam pemberdayaan masyarakat. Sebut saja Komunitas Blogger Banyumas. Jika melihat situs resmi dari Komunitas Blogger Banyumas yang beralamat di http://bloggerbanyumas.net/(diakses 14 Juli 2014), maka berita-berita yang tampil di halaman utama adalah kegiatan-kegiatan mereka memberikan pelatihan di desa-desa, organisasi masyarakat, bahkan institusi keagamaan seperti di vihara sekali pun.

Selain itu, terdapat komunitas "BlankOn Banyumas". "BlankOn Banyumas" merupakan komunitas pengembang dan pengguna piranti lunak dalam bahasa Banyumas yang didistribusikan secara gratis dan sumber kode terbuka (open source). Komunitas ini menaruh perhatian besar pada pengembangan teknologi informasi dan komunikasi di dunia perdesaan melalui Program Desa Melek IT dan Klinik TIK Perdesaan, seperti tercantum dalam halaman web http://blankonbanyumas.web.id/siapa-kami/ (diakses 14 Juli 2014).

Kabupaten Bandung, di mana Desa Cibiru Wetan berada di dalamnya, letaknya berbatasan dengan Kota Bandung. Ibukota Jawa Barat ini dikenal sebagai wilayah populer dalam perkembangan TIK. Berbagai komunitas TIK bermunculan di Bandung. Budi Rahardjo, pakar TIK dari Institut Teknologi Bandung mengungkapkan, secara umum komunitas-komunitas TIK di Bandung lebih fokus pada pengembangan inovasi-inovasi TIK mutakhir yang belum tentu tepat guna bagi kebutuhan masyarakat luas.

Komunitas blogger di Bandung sendiri, Batagor (Bandung Kota Blogger) lebih tertarik untuk menampilkan cerita-cerita para blogger Bandung. Komunitas Batagor memang terhitung cukup sering mengadakan kegiatan sosial seperti "Batagor 1 Traktir 1, Aksi Peduli Anak Jalanan", "BandungBerbagi”, dan "Bebersih Bandung Yuk". Namun kegiatan-kegiatan sosial yang mereka lakukan bukan gerakan pemberdayaan yang berkelanjutan.

Sedangkan komunitas berbasis penggunaan sistem operasi open source di Bandung, Indonesia Go Open Source (IGOS) Center Bandung belum terlalu bergerak ke ranah pemberdayaan masyarakat yang berkelanjutan melalui TIK. Pemberdayaan masyarakat dalam konteks ini adalah bagaimana intelektual-intelektual yang memiliki ketertarikan pada sistem open source dapat memanfaatkan pengetahuannya untuk dapat memberdayakan masyarakat. Walaupun begitu, IGOS Center Bandung berjasa dalam pembuatan aplikasi e-Demokrasi untuk Pilkada Jawa Barat. 
Meninjau dua fenomena di dua wilayah yang telah disebutkan beserta kecenderungan gerak intelektual di masing-masing wilayah, peneliti tertarik membahasnya dari sudut pandang gerakan kontrahegemoni. Dalam gerakan kontrahegemoni yang diformulasikan Gramsci, terdapat entitas yang dinamakan "intelektual organik".

Driyarkaya B. Herry Priyono, pengajar Sekolah Tinggi Filsafat (STF), dalam artikel "Gerhana Humaniora", menyatakan, 'intelektual organik' lebih khas karena kaitannya yang lebih erat dengan warga kebanyakan dan dengan proyek perubahan sosial tertentu dalam gelombang peristiwa di masyarakat. Mereka terutama adalah para anggota dari kelompok-kelompok progresif dalam masyarakat yang menyusun dan menciptakan gagasan-gagasan untuk mendasari proyek perubahan yang sedang diembannya (Priyono, 1993).

Menurut Herry, intelektual organik berbeda dengan "intelektual tradisional". intelektual tradisional lebih dimaksud sebagai kelompok cerdik-pandai dalam pengertian klasik. Kaum intelektual tradisional diikat oleh bahasa akademis universitas dan pendidikan tertentu yang kurang lebih sama, serta keterpisahannya dari massa kebanyakan. Sedangkan label "intelektual organik" yang menurut Herry identik dengan kaum intelektual yang menyusun gagasan-gagasan proyek perubahan lebih cocok diberikan kepada para pegiat TIK di Kabupaten Banyumas. Program-program yang mereka susun pun kebanyakan berorientasi untuk memantapkan kemampuan TIK bagi masyarakat awam agar tidak terjadi kesenjangan antara masyarakat kota dan masyarakat desa.

Lahirnya Gerakan Desa Membangun (GDM) juga dibidani oleh pegiat-pegiat TIK yang berasal dari Komunitas Blogger Banyumas, bekerja sama dengan INFEST Yogyakarta. Program-program yang dilakukan intelektual organik di kawasan Banyumas pun membuat desa-desa di kabupaten tersebut terciprati pengetahuan pemanfaatan TIK, termasuk Desa Melung.

Sedangkan beberapa pegiat TIK di wilayah Bandung sendiri, terutama yang berbasis di lingkungan akademik seperti Institut Teknologi Bandung (ITB), Universitas Pendidikan Indonesia (UPI), atau Institut Teknologi Telkom (IT-Telkom), tepat dikatakan sebagai 'intelektual tradisional'. Beberapa dari mereka terikat tradisi bahasa akademis universiter dan cenderung berjarak dari realitas masyarakat yang termarjinalkan.

Komunitas-komunitas seperti Batagor, tidak dapat disebut 'intelektual tradisional' karena mereka dipersatukan karena hobi blogging, bukan dalam lingkup akademik. Mereka juga tidak tepat dikatakan sebagai "intelektual tradisional" karena mereka tidak memunculkan gerakan atau komunitas yang berkomitmen dan telah konsisten dalam menciptakan perubahan kemasyarakatan lewat TIK.

Tidak semua pegiat TIK di Bandung bukan 'intelektual organik'. Terdapat pula komunitas "Relawan TIK Kota Bandung". Relawan TIK Kota Bandung yang terbentuk pada 23 November 2013 dan diketuai M. Fajar berkomitmen untuk berkontribusi dalam berbagai kegiatan pembangunan, kemasyarakatan serta berperan 
dalam tugas kemanusiaan. Caranya adalah dengan mengoptimalkan pemanfaatan TIK bagi kemaslahatan masyarakat dan kemajuan bangsa Indonesia. Namun, Relawan TIK Kota Bandung dalam kenyataannya belum menunjukkan perkem-bangan yang signifikan dalam kegiatan kemasyarakatan melalui pemanfaatan TIK. Belum ada publikasi dari hasil yang mereka kerjakan selama ini.

Ketiga, menurut pakar psikologi Universitas Indonesia, Adriano Rusfi, masyarakat yang jauh dari kota-kota besar seperti Jakarta, Bandung, Yogyakarta, dan lain sebagainya seringkali memiliki "kecemburuan sosial" yang lebih tinggi terhadap masyarakat kota. Terlebih, jika desa tersebut dianggap terbelakang dan tertinggal. Kecemburuan ini dapat melahirkan semangat untuk menyamai bahkan mengalahkan masyarakat yang tinggal di sekitar kota atau di kota sekali pun.

Hal ini dapat menjelaskan mengapa Desa Melung tampak lebih bersemangat untuk mengembangkan TIK di desa mereka. Margino, Kaur Keuangan Melung yang juga Pemimpin Redaksi situs desa mengatakan, selama ini Melung dicap sebagai desa tertinggal oleh pemerintah. Terlebih, jarak desa mereka cukup jauh dengan jarak "ibu kota" Kabupaten Banyumas, Purwokerto. Oleh karena itu, "ketertinggalan" mereka mendorong mereka untuk maju serta menghilangkan label "ketertinggalan" tersebut.

Sedangkan Desa Cibiru Wetan, yang jaraknya sangat dekat dengan perbatasan Kota Bandung dan Kabupaten Bandung (sekitar 6 kilometer) merupakan daerah suburban yang tidak memiliki masalah berarti terkait akses jaringan internet dan akses ke perkotaan. Desa Cibiru Wetan pun tidak dicap sebagai "desa tertinggal" oleh pemerintah. Balai desa pun telah dilengkapi akses internet cepat dengan tiga buah perangkat komputer.

Dengan fasilitas tersebut ditambah asumsi kepala desa bahwa sudah sekitar 70\% dari keseluruhan warga yang sudah mengerti TIK, maka urgensi pemberdayaan masyarakat lewat TIK Di Desa Cibiru pun tidak terlalu diprioritaskan seperti layaknya di Desa Melung. Hal ini menimbulkan aura bahwa desa mereka sudah "cukup Bandung" dan tidak terlalu berbeda dengan kota terdekat.

Fenomena ini dapat dijelaskan dalam konsep "iri" dari buku Envy: A Theory of Social Behavior karya Helmut Shoelck. Rasa "iri” ternyata berperan dalam proses inovasi. Max Scheler dan H.G. Barnett menyatakan, justru orang-orang "marah" lah yang mendukung terjadinya inovasi. Tendensi sikap menantang "Sekarang akan kutunjukkan kepada mereka!" melahirkan hasil yang produktif sebanding dengan energi destruktif yang bisa tercipta akibat rasa iri tersebut (Schoelck, 1987, p. 416). Lebih lanjut, Schoelck mengutip pernyataan H.G. Barnett yang menyatakan "kebencian" (Schoelck menyamakannya dengan "iri”) ditemukan dalam masyarakat kelas terstruktur.

Mereka yang iri adalah orang-orang yang tidak puas dengan posisi subordinat mereka. Seseorang yang memiliki rasa iri terhadap kelompok yang menurutnya lebih "berada" mendorongnya untuk menolak kontrol sosial yang menurutnya membuat inovasi terhambat dan memaksanya untuk menjadi kaum terpinggirkan. 
Pada akhirnya, penolakan tersebut dalam kondisi tertentu melahirkan inovasi yang cukup lama bertahan dan dapat diadopsi untuk mengakhiri dominasi kaum elit yang ingin ia lenyapkan (Schoelck, 1987, p. 402). Hal ini dapat menjelaskan mengapa Desa Melung, yang sudah lama mendapat julukan "desa tertinggal” dan terletak di wilayah yang tidak populer dalam inovasi TIK justru lebih giat dan bersemangat terkait pemanfaatan TIK di desa mereka.

\section{Simpulan}

Dari hasil penelitian dan analisis pengarusutamaan yang dilakukan Gerakan Desa Membangun (GDM), maka dapat disimpulkan bahwa proses pembangunan selama ini lebih banyak berorientasi dari atas ke bawah (top-down) dibandingkan dengan orientasi dari bawah ke atas (bottom-up). Akibatnya, desa sekadar menjadi objek pembangunan, bukan sebagai subjek pembangunan, sehingga yang terjadi sebenarnya pembangunan di desa, bukan pembangunan desa. GDM merupakan perjuangan dari sekelompok masyarakat desa untuk membuat desa menjadi subjek pembangunan. Perjuangan itu diwujudkan melalui strategi pembuatan dan pengelolaan media sendiri sebagai sarana pengarusutamaan berita desa untuk melawan hegemoni berita arus utama media besar.

Dinamika pengelolaan media komunitas masyarakat Desa Cibiru dan Desa Melung mengalami perbedaan yang cukup kontras. Media Komunitas di Desa Cibiru Wetan tidak begitu aktif. Desa yang sangat dekat dengan perbatasan Kota Bandung dan Kabupaten Bandung (sekitar 6 kilometer) merupakan daerah suburban yang tidak memiliki masalah berarti terkait akses jaringan internet dan akses ke perkotaan. Kondisi masyarakakat yang dianggap telah mengerti TIK, justru membuat urgensi pemberdayaan masyarakat lewat TIK di Desa Cibiru pun tidak terlalu diprioritaskan seperti layaknya di Desa Melung. Aktivis yang menggeluti bidang TIK kebanyakan lahir berdasarkan kesamaan hobi atau kebutuhan bisnis, seperti komunikas Blogger.

Berbeda dengan media komunitas di Desa Melung jauh lebih aktif dibandingkan dengan media komunitas di Desa Cibiru. Jarak yang relatif jauh dari ibu kota Kabupaten yaitu Banyumas membuat Desa Melung relatif tertinggal dalam kemajuan pembangunan TIK. "Rasa" ketertinggalan ini justru melahirkan kaum intelektual organik, kaum aktivis yang lahir dengan semangat perubahan, yang menjadi motor perkembangan pengelolaan media komunitas di desa mereka.

Dari sisi akademis, penelitian ini dapat dilanjutkan atau diperdalam pada aspek partisipasi warga dalam pengisian konten media atau jurnalisme warga. Sementara dari sisi praktis, agar pengarusutamaan berita desa dapat tersuarakan lebih luas, GDM dapat berinisiatif untuk membujuk media-media arus utama agar memberikan mereka kolom atau slot khusus bagi mereka.

\section{Daftar Pustaka}

Creswell, J. W. (1998). Qualitative Inquiry and Research Design Choosing Among Five Tradition. Sage Publication. 
Gatranews. (2014, 03 02). diakses dari from Gatra: https://www.gatra.com/nusantara1/jawa-1/48104-remotivi-siaran-tv-nasional-rugikan-daerah.html

Khoerudin. (2014, 06 03). Wawancara Peneliti. (T. Riskawati, Interviewer)

Margiono. (2014, 06 03). Wawancara Peneliti. (T. Riskawati, Interviewer)

Paramita, P. (2013, 10 27). "Strategi Pengarusutamaan Berita Desa”. Retrieved 04 06, 2017, from http://www.slideshare.net/pradna/pendampingan-arusutama-desa

Priyono, H. (1993). diakses 07 14, 2014, dari Uni Sosial Demokrat: http://www.unisosdem.org/kumtul_detail.php?aid=80\&coid=1\&caid=34\&auid= 3

Raharjo, B. (2014, 07 06). Wawancara Peneliti. (T. Riskawati, Interviewer)

Rivers, etc, W. E. (2008). Media Massa dan Masyarakat Modern. Kencana.

Satrio, A. B. (2014). Wawancara Peneliti. (T. Riskawati, Interviewer)

Schoelck, H. (1987). Envy: A Theory of Social Behavior. Indianapolis: Liberty Fund. Indianapolis: Liberty Fund.

Stake, R. E. (2009). Studi Kasus. In K. N. Denzin, \& Y. S. Lincoln, Handbook of Qualitative Research. Pustaka Pelajar.

Suparyo, Y. (2013, 09 25). http://desamembangun.or.id/2013/09/strategi-menggalangkekuatan-untuk-lantangkan-isu-perdesaan/. Retrieved 07 14, 2014, from Desa Membangun: http://desamembangun.or.id/2013/09/strategi-menggalangkekuatan-untuk-lantangkan-isu-perdesaan/

Suparyo, Y. (2014, 01 24). Wawancara Peneliti. (T. Riskawati, Interviewer)

Tarigan, A. (2009, 10 14). "Rural - Urban Economic Lingkages", Konsep \& Urgensinya Dalam Memperkuat Pembangunan Desa. Retrieved 04 06, 2017, from http://bappenas.go.id/en/data-dan-informasi-utama/makalah/artikel-majalahperencanaan/edisi-30-tahun-2003/rural---urban-economic-lingkages-konsep-urgensinya-dalam-memperkuat-pembangunan-desa-bagian-pertama-dari-duatulisan---oleh-antonius-tarigan/

Terjesen, S. (2004). Amartya Sen's Development as a Freedom. Journal of Social Science, 1(2). $\quad$ Retrieved $04 \quad 06, \quad 2017$, from https://www.researchgate.net/publication/27466009_Amartya_Sen\%27s_Develo pment_as_Freedom

Yin, R. K. (2005). Studi Kasus : Desain dan Metode. Raja Grafindo Persada.

(2013). diakses 06 29, 2014, from Pikiran Rakyat: http://www.pikiranrakyat.com/node/246307

(2014). diakses 07 13, 2014, dari Harian Haluan: http://www.harianhaluan.com/index.php/opini/28689-otonomi-desa-untuk-siapa

(2014). diakses 06 29, 2014, dari Data Statistik Indonesia: http://www.datastatistikindonesia.com/proyeksi/index.php?option=com_content\&task=view\&id=910\&I temid $=923$ 